\title{
RELATIONSHIP BETWEEN MANAGEMENT'S COMMITMENT WITH JOB SATISFACTION ACCORDING TO SHARI'AH-BASED QMS (MS1900:2014): AN EMPIRICAL STUDY AT MALAYSIAN HEI
}

Hj. Hasan Al-Banna bin Mohamed*

Faculty of Management \& Defence Studies

National Defence University of Malaysia (NDUM)

Malaysia

\section{Mohd Hamran Mohamad}

Faculty of Management \& Defence Studies

National Defence University of Malaysia (NDUM)

Malaysia

\section{Siti Arni Basir}

Department of Siasah Syar'iyyah, Academy of Islamic Studies

Universiti of Malaya (UM)

Malaysia

\section{Norlaila Mazura Mohaiyadin}

Faculty of Management \& Defence Studies

National Defence University of Malaysia (NDUM)

Malaysia

\section{Nur Surayya Mohd Saudi}

Faculty of Management \& Defence Studies

National Defence University of Malaysia (NDUM)

Malaysia

Faculty of Management \& Defence Studies

\section{Wong Wai Loong}

National Defence University of Malaysia (NDUM)

Malaysia

*Corresponding author's Email: hasanalbanna@upnm.edu.my

Peer-review under responsibility of $3^{\text {rd }}$ Asia International Multidisciplanry Conference 2019 editorial board (http://www.utm.my/asia/our-team/)

(C) 2019 Published by Readers Insight Publisher, lat 306 Savoy Residencia, Block 3 F11/1,44000 Islamabad. Pakistan,

info@ readersinsight.net

This is an open access article under the CC BY-NC-ND license (http://creativecommons.org/licenses/by-nc-nd/4.0/). 


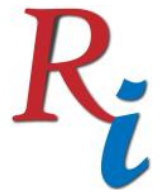

\section{Asia Proceedings of Social Sciences \\ (APSS) \\ www.readersinsight.net/APSS}

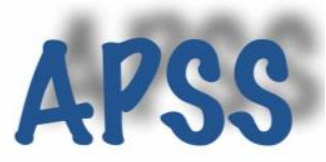

\section{Rese a r ch H igh I igh t s}

Management's commitment in an organisation plays an important role in ensuring the application of effective quality management system (QMS). This article explores the relationship between management's commitment of an organisation that implements Shari'ahbased QMS (MS1900:2014) with job satisfaction at Malaysian Higher Education Institution (HEI). The methodology of this study employed a qualitative design via a semi-structured interview conducted on selected respondents. The respondents consist of employees who are directly and actively involved with the implementation of MS1900 standard. The findings of this study show that management's commitment has apparently influenced job satisfaction among employees at HEI. Therefore, the results of this study can serve as a guide to ensure that the implementation of quality management system based on Shari'ah standards (MS1900) can be applied effectively, blessed and rewarded by Allah GTH.

Keywords: Management's Commitment, Shari'ah Based QMS (MS1900), Job Satisfaction, Malaysian HEI

\section{Research Objectives}

In general, the implementation of quality management system (QMS) in an organisation often produce positive impacts. Quality and effective terms are often associated with an effort being made to meet the needs and satisfaction of customers within an organisation, increase of productivity, and ensuring the products/services provided are best without any defect. Besides that, the quality aspect is also associated with the commitment factor of the management of an organisation fulfiling their customers' needs. In fact, in Islam, the idea of perfection in the production of a product/service can be attributed to all the creation of Allah GTH.

Hence, the importance of quality management in daily life has become a major requirement for everyone to apply it at all times. In fact, it is achievable with the commitment of an organisation that supports and encourages the implementation of effective management system. Thus, employees will be more committed to contribute to the success of their organisation when the employer demonstrates unwavering support (Karia \& Asaari, 2006). Besides that, Michalisin and White (2001) emphasised that the quality of commitment and leadership in an organisation is able to produce better customer satisfaction.

It is clear that an in-depth study should be undertaken to examine the relationship between management's commitment in an organisation that implements Shari'ah-based QMS (S-QMS) on the satisfaction of working amongst internal staff or customers. Therefore, the authors will discuss the dimensions of S-QMS in detail, parallel to what every Ummah practices based on the intention of worshiping Allah GTH to produce products/services that can benefit other parties. In this context, the researcher will focus on selected factors that influence successful implementation of S-QMS in Malaysian HEIs, which ultimately affects the level of job satisfaction among employees. Therefore, this study will focus on management's commitment factors that provide job satisfaction among staff in HEIs that implement S-QMS through MS1900 standards in Malaysia.

\section{Methodology}

This study adopted the qualitative research, which refers to case study as suggested by Stake (1997). The selected respondents involved the academic and non-academic staff of the Public and Private Universities in Malaysia, which have successfully implemented MS1900 and involved directly and actively. The researchers also used semi-structural interviews, direct 


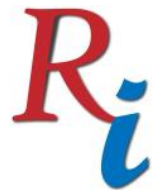

\section{Asia Proceedings of Social Sciences \\ (APSS) \\ www.readersinsight.net/APSS}

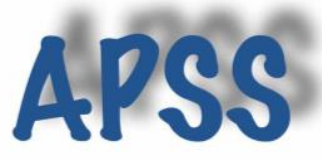

observation and analysis of documentary evidence as the primary data collection method. Secondary sources are derived from evidence of supporting documents and records that contain important information relevant to this study.

\section{Results and Findings}

The researchers transcribed the interview between respondents using the coding process using the NVivo ${ }^{\mathrm{TM}}$ software. The researchers found that the management's commitment factor was influencing job satisfaction when implementing S-QMS (MS1900) at Public and Private University. The result shows that the total amount of reference code for Private University is 59 for the management's commitment factor which were coded from non-academic staff (33), academic staff (15) and top management (11). Next, the coding process analysis for Public University. 20 reference codes were coded from non-academic staff, 9 were coded from academic staff and 8 were coded from the top management.

Researcher found that the top management's commitment in implementing S-QMS (MS1900) cannot be denied as the top management from the Vice Chancellor, Deputy Vice-Chancellors and Heads of Department together with the stakeholders, fully supported the implementation of MS1900. This further reflects that the top management is commited with a budget, which is often approved by the Centre for Quality Management in their organisation to implement MS1900 programmes annually.

In fact, the importance of commitment and support from the top managament is also shared by academic and non-academic staff. Overall, when referring to the results of this study, it is found that all respondents indicated that their leaders are very supportive with the implementation of MS1900.

\section{References}

Karia, N. \& Asaari, M. (2006). The effects of total quality management practices on employees' workrelated attitudes. The TQM Magazine, 18(1), 30-43.

Michalisin, M.D. \& White, G.P. (2001). An empirical study of the posturing - implementation gap in quality management. Quality Management Journal, 8(1), 34-51.

Stake, R. E. (1997). Case study methods in educational research: Seeking sweet water. In Richard M. Jaeger (ed.). Complementary Research Methods for Research in Education. Washington, DC: American Educational Research Association. 